\title{
Rupture of a Rudimentary Uterine Horn: A Case Report
}

\author{
Kouamé Arthur Didier*, Adjoby Cassou Roland, Konan Joachim, Effoh N’Drin Dénis, \\ Kakou Charles, Diomandé Fatoumata Alice, Koffi Soh Victor, Kouakou Firmin
}

Obstetrics and Gynaecology Department of the University Hospital of Cocody-Abidjan, Abidjan, Côte D’Ivoire

Email: *arthur.kouame@mail.huji.ac.il

How to cite this paper: Didier, K.A., Roland, A.C., Joachim, K., Dénis, E.N., Charles, K., Alice, D.F., Victor, K.S. and Firmin, K. (2017) Rupture of a Rudimentary Uterine Horn: A Case Report. Open Journal of Obstetrics and Gynecology, 7, 748-752. https://doi.org/10.4236/ojog.2017.77076

Received: May 17, 2017

Accepted: July 24, 2017

Published: July 27, 2017

Copyright $\odot 2017$ by authors and Scientific Research Publishing Inc. This work is licensed under the Creative Commons Attribution International License (CC BY 4.0).

http://creativecommons.org/licenses/by/4.0/

\begin{abstract}
Pregnancy in an abnormal uterus is a high-risk situation in obstetrics. Uterus bicornis unicollis with a rudimentary horn is often discovered incidentally. The aim of this report is to warn obstetricians about recurrent abdominal pain in the second trimester of pregnancy without any cause identified. Pregnancy can proceed in the rudimentary horn. We presented a case of a rupture of the rudimentary horn which occurred at 25 weeks of amenorrhea in an unmarried 19-year-old primigravida. The rudimentary horn was removed after performing an emergency laparotomy for an intraperitoneal hemorrhage with signs of shock. This abnormality is often revealed by uterine rupture, which usually occurs in the second trimester of pregnancy. Conclusion: We emphasize the importance of early diagnosis of this uterine abnormality, before pregnancy if possible. Undiagnosed, this condition evolves towards uterine rupture during pregnancy and requires emergency surgery with excision of the rudimentary horn.
\end{abstract}

\section{Keywords}

Uterine Rupture, Abdominal Pregnancy, Uterus Bicornis, Rudimentary Uterine Horn

\section{Introduction}

The embryology of uterus bicornis with a rudimentary horn is a consequence of the failure of progression of one of the two Müllerian ducts between the sixth and ninth week of gestation. This rudimentary horn may have a cavity with endometrial lining of the uterus, and thus can serve as a site of implantation during pregnancy [1] [2]. Pregnancy in a rudimentary horn usually results in its rupture which can lead to a life-threatening heavy bleeding. That is an extremely rare condition 10-fold less common than abdominal pregnancy [3]. We describe a 
clinical case of a rupture of the rudimentary horn which occurred at 25 weeks of amenorrhea.

\section{Observation}

An unmarried 19-year-old primigravida was referred to our service for persistent abdominal and pelvic pain. During this pregnancy, she had never attended any antenatal care service. Clinical examination showed a stable gene- ral condition with blood pressure $100 / 60 \mathrm{~mm} \mathrm{Hg}$ and pulse at 88 beats/min. The abdomen was slightly distended and sensitive with dullness in both flanks. Vaginal examination disclosed a single softened closed cervix without bleeding. The first ultrasound examination was performed and suspected an abdominal pregnancy of 25 weeks with fetal death. There were no signs of peritoneal effusion. During hospitalization, she presented peritoneal effusion syndrome with signs of shock. The patient was taken for emergent laparotomy, which revealed $300 \mathrm{ml}$ of blood and a deceased but morphologically normal fetus weighing 610 free in the abdominal cavity. After inspection, we discovered a rupture of the upper surface of a rudimentary left horn of a uterus bicornis unicollis. The left fallopian tube and the left ovary appeared normal and were connected on this rudimentary horn. The rudimentary horn was removed by clamping, ligating and cutting its attachment to the right horn. The postoperative course was uneventful and the patient was able to leave the hospital on post-operative day 7 (Figure 1 and Figure 2).

\section{Discussion}

Mauriceau described the first case of uterine rupture during pregnancy in a rudimentary horn in 1669 [4]. This report is the first case documented in our department at the Teaching Hospital of Cocody. According to 47 studies of 570,000 women, the incidence of uterine malformations is $0.5 \%$, and of these, $5 \%$ are horned uterus [1]. The incidence of rudimentary horn pregnancy is estimated at $1 / 100,000$ to $1 / 140,000$ [2]. Ten percent of these rudimentary horns

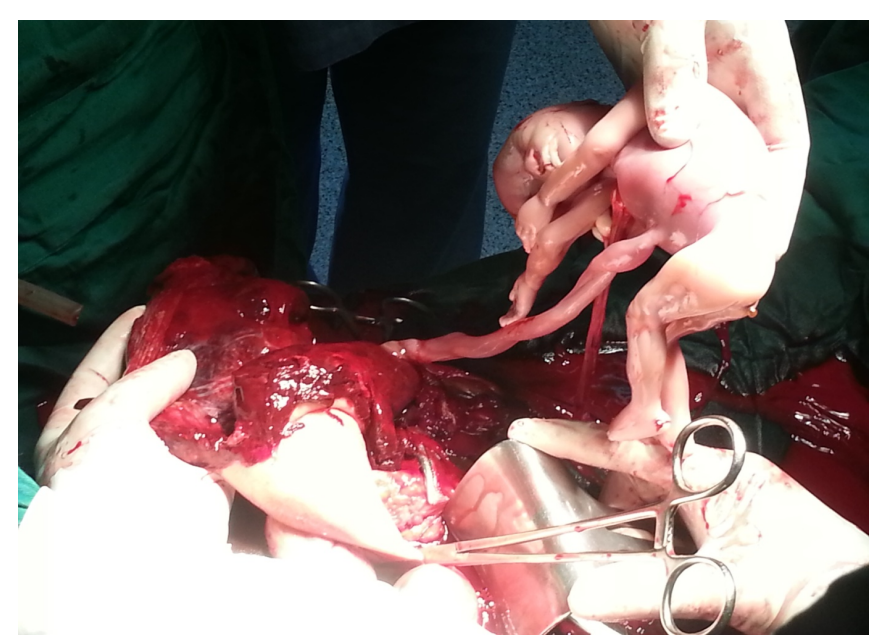

Figure 1. Photo showing the uterine rupture with a dead fetus. 


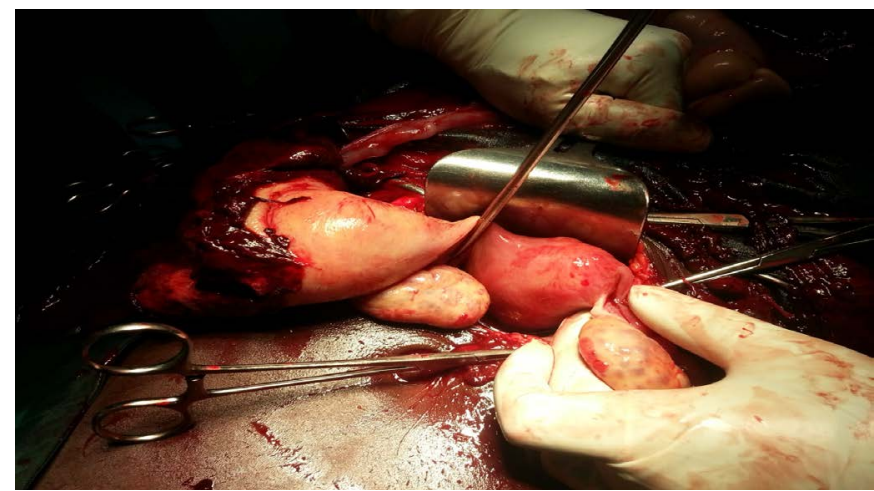

Figure 2. Photo showing the 2 horns of the uterus with the 2 ovaries. The ruptured horn is at the left side of the photo.

communicate with the main uterine horn and $35 \%$ have a cavity [1]. There is a slight predominance of the rudimentary horn at the right side potentially related to the more caudal location of the left Müllerian duct [4]. The implantation of the egg in the aplastic horn is usually the result of transperitoneal migration of a spermatozoid to the rudimentary horn. Since the elasticity of the horn is limited, the risk of its rupture during pregnancy is high. This can occur early in the second trimester [5].

Diagnosis of pregnancy in a uterine horn is difficult owing to the non-specific nature of the symptoms, mainly severe abdominal pain in the second trimester. The differential diagnosis might include ectopic, corneal or isthmic pregnancy [6]. It is associated with intraperitoneal hemorrhage, which can be revealed by ultrasound examination. Rupture frequently leads to emergency surgery, at which point a diagnosis is typically established [7]. Laparoscopy may be a reasonable approach in uncertain circumstances. Earlier detection of uterine malformations by ultrasound or magnetic resonance imaging (MRI) examination may be useful to prevent this devastating obstetrical accident which can lead to maternal mortality [8].

When uterus bicornis with rudimentary horn is discovered incidentally without pregnancy, the rudimentary horn should be excised when possible. This procedure can be performed using a laparoscopic approach [9] [10]. If pregnancy in a rudimentary horn is diagnosed in the first trimester, it may be reasonable to continue the pregnancy with ultrasound monitoring close to a term of 28 weeks to allow for fetal lung maturation. Surgical intervention can be performed when the estimated fetal mass is greater than 1000 grams or if the thickness of the myometrium at any point of the wall is less than $5 \mathrm{~mm}$ [5].

Fewer than $5 \%$ of cases are recognized before laparotomy must be performed for hemorrhagic shock [11]. These pregnancies are also at risk of placenta accreta and percreta, probably because of the poor quality of the endometrium and low decidualization [11] [12]. In a series of 7 pregnancies implanted in the uterine rudimentary horn, Heinonen [13] noticed three cases of placenta accreta (43\%), which was also favored by pathological examination of our case. In settings with limited access to health care resources, this condition could lead to 
maternal death.

\section{Conclusion}

Early diagnosis of a rudimentary horn pregnancy is usually accidental. Ultrasound examination may be a useful tool to detect these pregnancies in the first trimester. Abdominal pain occurring in the second trimester of pregnancy without identified cause should alert the clinician to this condition, and ultrasound examination will diagnose an intraperitoneal hemorrhage. Undiagnosed, this condition evolves towards uterine rupture and requires emergency surgery with excision of the rudimentary horn.

\section{Informed Consent}

The patient had given her consent for the reported case to be published.

\section{References}

[1] Nahum, G. (1998) Uterine Anomalies. How Common Are They, And What Is Their Distribution among Subtypes? The Journal of Reproductive Medicine, 43, 877-887.

[2] Johansen, K. (1983) Pregnancy in a Rudimentary Horn. Obstetrics \& Gynecology, 61, 565-567.

[3] Gonçalves, E., Prata, J.P., Ferreira, S., Abreu, R., Mesquita, J., Carvalho, A. and Pinheiro, P. (2013) An Unexpected Near Term Pregnancy in a Rudimentary Uterine Horn. Case Reports in Obstetrics and Gynecology, Article ID: No. 307828, 1-4.

[4] Nahum, G. (2002) Rudimentary Uterine Horn Pregnancy. The 20th Century Worldwide Experience of 588 Cases. The Journal of Reproductive Medicine, 47, 151-163.

[5] Schmied, R., Sentilhes, L., Baron, M., Grzegorczyk, V., Resch, B. and Marpeau, L. (2008) Récidive d'une rupture utérine sur corne rudimentaire d'un utérus pseudo-unicorne à 25 semaines d'aménorrhée: à propos d'un cas. Gynécologie Obstétrique \& Fertilité, 36, 296-298. https://doi.org/10.1016/j.gyobfe.2007.11.023

[6] AFS (1988) The American Fertility Society Classification of Adnexal Adhesions, Distal Tubal Occlusions, Tubal Occlusion Secondary to Tubal Ligation, Tubal Pregnancies, Mullerian Anomalies and Intrauterine Adhesions. Fertility and Sterility, 49, 944-955. https://doi.org/10.1016/S0015-0282(16)59942-7

[7] Kuscu, N.K., Lacin, S., Kartal, O. and Koyuncu, F. (2002) Rupture of Rudimentary Horn Pregnancy at 15th Week of Gestation: A Case Report. European Journal of Obstetrics \& Gynecology and Reproductive Biology,102, 209-210.

https://doi.org/10.1016/S0301-2115(01)00600-5

[8] Fuchs, F., Guillot, E., Cordier, A.G., Chis, C., Raynal, P. and Panel, P. (2008) Rupture d'une corne utérine rudimentaire non communicante gravide sur un utérus pseudo-unicorne à 23 semaines d'aménorrhée à propos d'un cas. Gynécologie Obstétrique \& Fertilité, 36, 400-402. https://doi.org/10.1016/j.gyobfe.2007.11.016

[9] Dicker, D., Nitke, S., Shoenfeld, A., Fish, B., Meizner, I. and Ben-Rafael, Z. (1998) Laparoscopic Management of Rudimentary Horn Pregnancy. Human Reproduction, 13, 2643-2644. https://doi.org/10.1093/humrep/13.9.2643

[10] Soundararagan, V. and Rai, J. (2000) Laparoscopic Removal of a Rudimentary Uterine Horn during Pregnancy. A Case Report. The Journal of Reproductive Medicine, 45, 599-602. 
[11] Sfar, E., Zine, S., Bourghida, S., Bettaieb, A. and Chelli, H. (1994) La grossesse dans une corne utérine rudimentaire: principales formes cliniques, à propos de 5 cas. Revue Francaise De Gynecologie et D'Obstetrique, 89, 21-26.

[12] Oral, B., Guney, M., Ozsay, M. and Sonal, S. (2001) Placenta Acreta Associated with a Ruptured Pregnant Rudimentary Uterine Horn. Case Report and Review of the Literature. Archives of Gynecology and Obstetrics, 268, 100-102. https://doi.org/10.1007/s004040000140

[13] Heinonen, P.K. (1997) Unicornuate Uterus and Rudimentary Horn. Fertility and Sterility, 68, 224-230. https://doi.org/10.1016/S0015-0282(97)81506-3

Submit or recommend next manuscript to SCIRP and we will provide best service for you:

Accepting pre-submission inquiries through Email, Facebook, LinkedIn, Twitter, etc. A wide selection of journals (inclusive of 9 subjects, more than 200 journals)

Providing 24-hour high-quality service

User-friendly online submission system

Fair and swift peer-review system

Efficient typesetting and proofreading procedure

Display of the result of downloads and visits, as well as the number of cited articles Maximum dissemination of your research work

Submit your manuscript at: http://papersubmission.scirp.org/

Or contact ojog@scirp.org 